\title{
Antimicrobial activity of Plectranthus barbatus (Lamiacea)
}

\author{
Regina Célia Sales Santos Veríssimo, Thais Honório Lins, Maria Lysete de Assis Bastos, \\ Patrícia de Albuquerque Sarmento, Valter Alvino*, Maria Gabriella Silva Araujo, Andressa Letícia Lopes Silva, \\ João Xavier Araújo-Júnior
}

From 5th Congress of the Brazilian Biotechnology Society (SBBIOTEC)

Florianópolis, Brazil. 10-14 November 2013

\section{Introduction}

The medicinal potential of plant is due to the presence of active principles, capable of producing several pharmacological effects such as analgesic, antiseptic agents, diuretics, expectorants, tranquilizers, digestive healing, emollients, anti-diarrhoeal, among others [1]. The deep cultural roots of the Brazilian population facilitated the permanence of the use of herbal medicine to the present day acknowledging its effectiveness and legitimacy. [2] A strong scientific interest in herbal medicine has grown in recent years, which has led to the development of several studies that were based on popular practices with the use of plants for various therapeutic purposes [3]. One of medicinal plants, Plectranthus barbatus, is traditionally used as anti-inflammatory and antifungal agents, and has been recognized for its effects against the bacterias that cause dental caries such as Streptococcus mutans and Streptococcus sobrinus [4].

\section{Objective}

To evaluate the antimicrobial potential of leaf extracts from Plectranthus barbatus front of species which often causing infection of wounds.

\section{Methodology}

The extracts were prepared by maceration in $96 \%$ ethanol. The crude ethanol extract was tested against microorganisms:

Staphylococcusaureus, Staphylococcusepidermidis, Pseudomonasaeruginosa, Enterobacteraerogenes, Salmonellaenterica, Streptococcuspneumoniae, Acinetobactercalcoaceticus, EscherichiacoliandCandidaalbicans by agar perforation methods. Subsequently, it was determined the Minimum

\footnotetext{
Federal University of Alagoas, Maceió, AL, Brazil
}

Inhibitory Concentration (MIC) by the broth micro dilution method using the culture media Brain Heart Infusion (BHI) broth in 96-well plates. The solubilization of the samples was performed with saline solution $0.9 \%$ and Tween 80 . The positive control used was Ceftriaxone. It was used as a developer 2,3,5-triphenyl tetrazolium chloride $(0.5 \mathrm{mg} / \mathrm{ml})$. All experiments were performed in triplicate. Statistical analysis was performed using Kruskal-Wallis test. Data were considered significant when $\mathrm{p}<0,05$.

\section{Results and conclusion}

The extract showed zone of inhibition average of 14,33 $( \pm 0,47)$ against Staphylococcus aureus is considered active according to the methodology AYRES [5]. The MIC had favourable outcomes for Staphylococcus aureus $(3,12 \mathrm{mg} / \mathrm{ml})$ Staphylococcus epidermidis $(6,25 \mathrm{mg} / \mathrm{ml})$, Streptococcus pneumoniae $(6,25 \mathrm{mg} / \mathrm{ml})$ and Escherichia coli $(6,25 \mathrm{mg} / \mathrm{ml})$. The results allowed to conclude that Plectranthus barbatus possesses the ability to inhibit pathogenic bacteria, proving that possesses antimicrobial activity that are prospects for obtaining natural antibiotics. The healing properties, their cytotoxic potential, as well as the development of bioproducts, specifically for infected wound, are underway.

\section{Published: 1 October 2014}

\section{References}

1. Santos RL, Guimaraes GP, Nobre MSC, Portella AS: Analysis about phytotherapy as an integrating practice in the Brazilian Unified Health System (UHS). Brazilian Journal of Medicinal Plants 2011, 13:486-491.

2. Santos OJ, Torres OJM: A evolução da fitoterapia na cicatrização em cirurgia. BADS, Brazilian Archives of Digestive Surgery 2012, 25:139.

3. Lucena PL, Ribas-Filho JM, Mazza M, Czeczko NG, Dietz UA, Correa Neto MA, Henriques GS, Santos JO, Ceschin AP, Thiele ES: Evaluation of the 
aroeira (SchinusterebinthifoliaRaddi) in the healing process of surgical incision in the bladder of rats. Acta Cirurgica Brasileira 2006, 21:46-51.

4. Figueiredo NLL: Efeito inibitório de extractos de plantas no crescimento e factores de virulência de streptococcus sobrinus e streptococcus mutans. Dissertation, University of Lisbon, Department of Chemistry and Biochemistry; 2009

5. Ayres MCC, Brandão MS, Vieira-Júnior GM, Menor JCAS, Silva HB, Soares MJS, Chaves MH: Antibacterialactivity of useful plants and chemical constituents of the roots of Copernicia prunifera. Brazilian Journal of Pharmacognosy; 2008:18:90-97.

doi:10.1186/1753-6561-8-S4-P264

Cite this article as: Santos Veríssimo et al: Antimicrobial activity of Plectranthus barbatus (Lamiacea). BMC Proceedings 2014 8(Suppl 4):P264.

\section{Submit your next manuscript to BioMed Central} and take full advantage of:

- Convenient online submission

- Thorough peer review

- No space constraints or color figure charges

- Immediate publication on acceptance

- Inclusion in PubMed, CAS, Scopus and Google Scholar

- Research which is freely available for redistribution

Submit your manuscript at www.biomedcentral.com/submit 